\title{
Influence Factors Analysis on Rural Land Circulation under the Perspective of Financial Support -Taking Tongren region of Guizhou Province as an Example
}

\author{
Piao Jing \\ Northeastern University, Shenyang, Liaoning, 110819 \\ China \\ Dalian Nationalities University, Dalian, Liaoning, \\ 116600 China
}

\author{
Jin Keyi \\ Dalian University, Dalian, Liaoning, 116600 \\ China
}

\begin{abstract}
Based on the rural of the Tongren region in Guizhou Province, the rural land circulation index system has been structured, and with the field survey data as samples, it analyzes the rural land circulation index with the method of principal component analysis factors, the result of which shows that the age, physical condition, the number of workers, nonagricultural income ratio, land price reasonable proportion and rural financial support are the main components of the land circulation intention, and then there is the principal component factor regression analysis to establish regression equation model, lastly according to the regression analysis model, the rural land circulation suggestions and countermeasures are given under the perspective of financial support.
\end{abstract}

Keywords-Keywords-land circulation; intention; financial support; principal component analysis ;

\section{INTRODUCTION}

Since the 21st Century, the market economy has made rapid development in China, and non-agricultural employment level of agricultural labor has improved. The improvement of rural non-agricultural employ ment level makes the current rural utilization and land circulation mechanism no longer meet this requirement, and individual areas even have a serious desolation phenomenon[1][2]. In 2010, Li Qiyu and Zhang Wenxiu[3] constructed Logistic regression model to analyze farmers' rural land operation rights circulation willingness and influence factors, by taking farmer questionnaires in rural areas of Chengdu City and Chongqing City as the basis. The result showed the factors of influencing farmers' rural land circulation willingness: rural land circulation price, whether there are rural land circulation intermediary and government subsidies to purchase social insurance and regional economy development level influencing farmers' rural land transfer-in willingness greatly, family income and composition, rural land circulation price, whether there are rural land circulation intermediary and government subsidies to purchase social insurance influencing famers' rural land transfer-out willingness greatly. $\mathrm{Xu}$ Zhenyuan and Kong Xiangzhi[4] used logistics model to analyze the deep level reasons of influencing transfer-out rural land farmers to choose circulation period, thinking that the lack of endowment insurance and unemployment insurance is an important influence factor of preventing farmers from obtaining long-term land circulation usage rights. This paper, based on literature review and interview survey to construct index system of influencing rural land circulation factors, conducts actual field questionnaires and collects data from 500 households of farmers in Tongren City of Guizhou Province. Then it takes these survey data as the samples for the main component analysis of index system, using the main component to construct corresponding regression model. Finally, according to the regression analysis result, it puts forward suggestions and strategies for rural land circulation from the perspective of financial support.

\section{BASIC SITUATION ANALYSIS OF RURAL LAND CIRCULATION AND FINANCIAL SUPPORT IN TONGREN CITY}

\section{A. Basic Situation ofRural Land Circulation}

In 2008, for example, the total agricultural land area in Tongren City was 2,600,000 acres, and the average agricultural land area was 0.66 acre. The land circulation area in this region was 272,000 acres, accounting for $10.46 \%$ of the agricultural land area. The total agricultural land area of Tongren City was 187,000 acres, with average of 0.78 acre. The land circulation area was 20,100 acres, accounting for $10.73 \%$ of the total agricultural land area. The individual area was more slowly, with only 80,000 acres, accounting for $5.30 \%$ of the total agricultural land area. This still existed a certain distance with national land circulation implementation situation $11.00 \%$. Also, compared with other surrounding provinces and regions, the difference was greater, with specific data as shown in Table 2-1 below. Table 2-1 RURAL LAND CIRCULATION SITUATION IN DIFFERENT REGIONS IN 2008

\begin{tabular}{|c|c|c|c|}
\hline \multirow{4}{*}{ Region } & Province & $\begin{array}{c}\text { Land circulation area } \\
\text { (ten thousand acres) }\end{array}$ & $\begin{array}{c}\text { Ratio of agricultural } \\
\text { land area }\end{array}$ \\
\hline \multirow{4}{*}{ Westem } & Tongren, Guizhou & 27.20 & $10.46 \%$ \\
\cline { 2 - 4 } & Chongqing & 320.30 & $16.00 \%$ \\
\cline { 2 - 4 } & Guang'an, Sichuan & 43.60 & $17.90 \%$ \\
\cline { 2 - 4 } & Guigang, Guangxi & 75.64 & $13.67 \%$ \\
\hline Central & Fuzhou, Jiangxi & 62.42 & $18.31 \%$ \\
\cline { 2 - 4 } & Huaihua, Hunan & 322.86 & $12.00 \%$ \\
\hline Eastem & Zhuhai, Guangdong & 266.70 & $31.70 \%$ \\
\hline National & - & - & $11.00 \%$ \\
\hline
\end{tabular}


Basic Form of Rural Land Circulation

Currently, the main form of land circulation in Guizhou Province is:

First, subcontracting. The owners subcontract land contracting operation rights to land contracting farmers, and the both parties sign subcontracting agreement and make clear the both parties' rights and obligations in subcontract agreement.

Second, shares. The so-called shares refer to that, in order develop agricultural economy, land contracting parties take land contract operation rights as the equity, voluntarily jo in the joint-stock companies or cooperatives and conduct operation according to the rules of the company. The farmers themselves are the shareholders of the company, and farmers can enjoy the company's operation benefit according to their share proportion in the company.

Third, rental. It is the rural land circulation form of specification generally accepted by the parties according to market laws.

Fourth, swap. Swap is a popular means in the initial period of land circulation.

\section{B. Financial Support of Rural Land Circulation}

In the financial support aspect of rural land circulation, Tongren City first launched rural land circulation operation rights for mortgage loans. Rural land circulation makes land centralized-cultivation become possible. In land centralizedoperation process, it needs a lot of fund input. Thus, the rural financial demand will become stronger, which needs the powerful support of financial industry. But on the other hand, land circulation also brings a good development opportunity for the financial industry. Only the land usage rights flow can realize land production operation scaled and land benefit maximu $\mathrm{m}[5,6,7]$.

\section{EMPIRICAL ANALYSIS OF RURAL LAND CIRCULATION WILLINGNESS}

\section{A. Selection of Index System}

This paper also refers to a lot of domestic and foreign literature materials and research experience about land circulation. Then combined with the actual situation, the factors of influencing rural land circulation willingness in Tongren City are divided into three aspects of individual factor, family factor and social factor, with specific index factors as shown in Table 3-1 below.

\section{Table 3-1 RURAL LAND CIRCULATION} WILLINGNESS INDEX SYSTEM

\begin{tabular}{|c|c|c|}
\hline $\begin{array}{l}\text { First class } \\
\text { index }\end{array}$ & Second class index & Third class index \\
\hline \multirow{10}{*}{$\begin{array}{l}\text { Rural land } \\
\text { circulation } \\
\text { willingness }\end{array}$} & \multirow{3}{*}{ Individual factor } & $\mathrm{X} 1$ : age \\
\hline & & X2: cultural level \\
\hline & & X3: physical condition \\
\hline & \multirow{3}{*}{ Family factor } & X4: family income \\
\hline & & X5: family labor quantity \\
\hline & & X6: non-agricultural income proportion \\
\hline & \multirow{4}{*}{ Social factor } & $\mathrm{X} 7$ : whether land circulation price is rational \\
\hline & & $\begin{array}{l}\text { X8: whether understanding government's } \\
\text { relevant policies for land circulation }\end{array}$ \\
\hline & & $\begin{array}{l}\text { X9: whether there is land circulation } \\
\text { intermediary }\end{array}$ \\
\hline & & $\begin{array}{l}\text { X10: whether rural financial support is } \\
\text { perfect }\end{array}$ \\
\hline
\end{tabular}

\section{B. Data Collection and Collation}

This paper designs the questionnaire table according to the ten index factors of $\mathrm{X} 1-\mathrm{X} 10$ of rural land circulation willingness index system in Tongren City of Guizhou Province given by Table 3-1. It selects rural household members in Tongren City as the questionnaire subjects, also, in order to ensure the reliability of the survey results, it adopts random selection principle in choosing survey subjects. Finally, 500 pieces of questionnaires were given and they were recovered, with the recovery rate of $100 \%$. According to the questionnaire scoring situation, it eliminates problematic questionnaires for 25 pieces, with effective questionnaires of 475 pieces and the effective rate of $95 \%$.

\section{Main Component Analysis}

It uses statistics analysis software SPSS20.0 for main component analysis of 10 influence factor indexes of influencing rural land circulation willingness, finding the most important factor of rural land circulation in Tongren City(main factor), then it uses the main component factor obtained by empirical analysis, using the linear regression analys is method to construct the comprehensive evaluation function of influencing rural land circulation willingness in Tongren City. The analysis result is as follows. Table 3-2 KMO AND BARTLETT TESTING

\begin{tabular}{|c|c|c|}
\hline \multicolumn{2}{|c|}{ Sampling enough degree of } & .837 \\
\hline \multicolumn{3}{|c|}{ Approximate card square } \\
\hline & & 308.265 \\
\hline \multirow{2}{*}{$\begin{array}{l}\text { Bartlett sphericity } \\
\text { testing }\end{array}$} & $\mathrm{df}$ & 318 \\
\hline & Sig. & .001 \\
\hline
\end{tabular}

Table 3-2 gives the KMO and Bartlett testing result, and when KMO is closer to 1 , it is more suitable for factor analys is. Fro $m$ the table, we can obtain KMO value of 0.837 , which shows it is suitable for factor analysis. Bartlett sphericity testing result shows that Sig value is 0.001 , less than the significant level of 0.05 , thus rejecting the null hypothesis. It shows that the there exists correlation between variables, and once again, it is proved to be suitable for factor analys is.

Table 3-3 TOTAL VARIANCE OF EXPLANATION

\begin{tabular}{|c|c|c|c|c|c|c|c|c|c|}
\hline \multirow[t]{2}{*}{ Index } & \multicolumn{3}{|c|}{ Initial feature value } & \multicolumn{3}{|c|}{ Extracting square and load } & \multicolumn{3}{|c|}{ Rotating square and load } \\
\hline & Total & \begin{tabular}{c|}
$\begin{array}{c}\text { Variance } \\
\%\end{array}$ \\
\end{tabular} & \begin{tabular}{c|} 
Accumulation \\
$\%$
\end{tabular} & Total & $\begin{array}{c}\text { Variance } \\
\%\end{array}$ & $\begin{array}{c}\text { Accumulation } \\
\%\end{array}$ & Total & \begin{tabular}{|c|} 
Variance \\
$\%$
\end{tabular} & $\begin{array}{c}\text { Accumulation } \\
\%\end{array}$ \\
\hline $\mathrm{x} 1$ & 2.356 & 37.605 & 37.605 & 2.356 & 37.605 & 37.605 & 2.652 & 30.162 & 30.162 \\
\hline $\mathrm{x}_{2}$ & 1.669 & 25.043 & 63.648 & 1.669 & 25.043 & 63.648 & 2.107 & 29.238 & 59.400 \\
\hline $\mathrm{x} 3$ & 1.143 & 19.134 & 81.782 & 1.143 & 19.134 & 81.782 & 1.462 & 22.382 & 81.782 \\
\hline $\mathrm{x} 4$ & .954 & 8.019 & 89.801 & & & & & & \\
\hline $\mathrm{x} 5$ & .687 & 5.225 & 94.026 & & & & & & \\
\hline $\mathrm{x} 6$ & .526 & 2.324 & 96.350 & & & & & & \\
\hline$x_{7}$ & .317 & 1.853 & 98.203 & & & & & & \\
\hline $\mathrm{xs}$ & .201 & .875 & 99.078 & & & & & & \\
\hline $\mathrm{X} 9$ & .106 & .537 & 99.615 & & & & & & \\
\hline $\mathrm{x} 10$ & .071 & .385 & 100.000 & & & & & & \\
\hline
\end{tabular}


Extraction method: main component analys is

Table 3-3 gives factor contribution rate result. It shows that only the feature values of the first three factors are greater than 1 , and the total of the feature values of the first three factors accounts for $81.782 \%$ of the total feature value. Thus, it extracts the three factors as the main factor. Table 3-4 ROTATING COMPONENT MATRIX

\begin{tabular}{|l|r|r|r|}
\hline & $\begin{array}{r}\text { Component } \\
1\end{array}$ & $\begin{array}{r}\text { Component } \\
2\end{array}$ & $\begin{array}{r}\text { Component } \\
\text { X1 }\end{array}$ \\
\hline $\mathrm{X} 2$ & .715 & -.087 & .117 \\
$\mathrm{X} 3$ & .237 & .108 & -.055 \\
$\mathrm{X} 4$ & .739 & .009 & .067 \\
$\mathrm{X} 5$ & .115 & .203 & -.101 \\
$\mathrm{X} 6$ & .106 & .792 & .049 \\
$\mathrm{X} 7$ & -.058 & .807 & .007 \\
$\mathrm{X} 8$ & .098 & -.073 & .835 \\
$\mathrm{X} 9$ & -.135 & -.113 & .204 \\
$\mathrm{X} 1$ & .037 & .107 & .327 \\
0 & -.019 & .005 & .796 \\
\hline
\end{tabular}

Extraction method: main component analysis

From Table 3-4, we can see that, the highest correlation with main component 1 is $\mathrm{X} 1$ and $\mathrm{X} 3$ of the two indexes. Main component 1 is ruled as "individual factor", and the weight coefficient is as shown in Table 3-4. The highest correlation with main component 2 is X5 and X6 of the two indexes, and main component 2 is ruled as "family factor", and the weight coefficient is as shown in Table 3-4. The highest correlation with main component 3 is X7 and X10 of the two indexes, and main component 3 is ruled as "social factor", with its weight coefficient as shown in Table 3-4.

Table 3-5 COMPONENT SCORING COEFFICIENT MATRIX

\begin{tabular}{|l|r|r|r|}
\hline & $\begin{array}{r}\text { Component } \\
1\end{array}$ & $\begin{array}{r}\text { Component } \\
2\end{array}$ & $\begin{array}{r}\text { Component } \\
3\end{array}$ \\
\hline $\mathrm{X} 1$ & .335 & -.086 & .104 \\
$\mathrm{X} 2$ & .139 & .117 & -.009 \\
$\mathrm{X} 3$ & .360 & .006 & .007 \\
$\mathrm{X} 4$ & .086 & .159 & -.063 \\
$\mathrm{X} 5$ & .058 & .405 & .028 \\
$\mathrm{X} 6$ & -.007 & .432 & .001 \\
$\mathrm{X} 7$ & .009 & -.005 & .447 \\
$\mathrm{X} 8$ & -.097 & -.083 & .133 \\
$\mathrm{X} 9$ & .093 & .068 & .152 \\
$\mathrm{X} 1$ & & .002 & .408 \\
0 & -.007 & &
\end{tabular}

Extraction method: main component analysis

Table 3-5 gives the main component factor scoring data calculated by component scoring coefficient matrix, reflecting the specific scoring situation of each farmer for land circulation willingness data on each influence factor. According to empirical scoring data, it constructs factor scoring function.

$$
\left\{\begin{array}{l}
F A C 1=0.335 X 1+0.139 X 2+\cdots-0.007 X 10 \\
F A C 2=-0.086 X 1+0.117 X 2+\cdots+0.002 X 10 \\
F A C 3=0.104 X 1-0.009 X 2+\cdots+0.408 X 10
\end{array}\right.
$$

By taking main component variance contribution rate as the weight, it constructs the comprehensive evaluation model of influencing rural land circulation willingness in Tongren City.

$F=0.30162 F A C 1+0.29238 F A C 2+0.22382 F A C 3$

Different periods of rural land circulation willingness questionnaire data are put into the above comprehensive evaluation model, namely, it can make comprehensive evaluation analysis of rural land circulation willingness in Tongren City. Corresponding government management units can adopt corresponding land circulation policies flexibly according to evaluation analys is results, so as to accelerate the land circulation scale in Tongren City.

\section{SUGGESTIONS AND COUNTERMEASURES OF RURAL LAND CIRCULATION FROM THE FINANCIAL PERSPECTIVE}

\section{A. Expanding Loan Channel and Innovating Financial Products}

First, the financial institutes in Tongren City should positively explore more types of financial products to support rural agricultural land circulation work. Second, Tongren financial institutes can do special things, namely, setting up a business department for rural area, to cope with the land circulation loan. Finally, Tongren government management department can launch relevant implementation methods for the rural land circulation loan.

\section{B. Improving and Perfecting Rural Financial Service System}

In order to improve and perfect rural financial service system, government department should do the following points: First, government should open rural financial market. Second, government should innovate rural financial system. Third, government should improve rural financial service $[8,9,10]$.

\section{Cultivating and Developing Rural Land Circulation Intermediary Service Institutions}

From the status, it still lacks of a mesh and multi-functional service system. And, the quantity and distribution situation of land circulation intermediary institutions are not reas onable. Government should strengthen legislation system, standardize the overall regulation management and standardize the nature and role of intermediary institution. Also, they must provide a certain financial subsidiary measure, thus, it can guarantee the stability of social environment. 


\section{REFERENCES}

[1] Dieninger K, Feder G. Land Institution and Land Markets[J]. World Bank Policy Research Working Paper, 1998.

[2] Carter M R, Zimmerman F. The Dynamic Costs and Persistence of Asset Inequality in an Agrarian Economy[J]. Journal of Development Economics, 2000(63):265-302.

[3] Li Qiyu, Zhang Wenxiu. Analysis on Rural Operation Rights Circulation Willingness and Its Influence Factors in Urban and Rural Context Background---Based on the Survey Data of 428 Households of Farmers in Chengdu and Chongqing Area[J]Agricultural Technical Economy, 2010(05):47-54.

[4] Xu Zhenyuan, Kong Xiangzhi. Empirical Analysis on Influence Fact ors of Transfer-out Land Circulation Period-Based on Transferout Farmers' Benefit and Risk Perspective[J]. Agricultural Technology Economy, 2010(07):30-40.

[5] Liu An'qi. How Financial Industry Serves for Rural Economy under Land Circulation Rights[J]. Hainan Finance, 2009(05):75-76.

[6] Hu Rongen, Tian Tao. Flowing Land-Land Circulation Survey in Tongren City of Guizhou Province[M]. Beijing: Beijing University Press, 2010
[7] Yang Jia, Tan Zhixi. Analysis on Rural Land Circulation Behavior in Minority Area of Wulinshan-Based on the Survey of Enshizhou Farmers[J]Journal of Hubei College for Nationalities(Philosophy and Social Science Edition), 201 1,29(06):64-69.

[8] Wang Chunguang. Social Analysis on New Generation of Migrant Workers' City Integrating Process and Problems[J]. Youth Exploration, 2010(03): 5-15.

[9] Wang Huiqing, Yin Shaohua. Problems and Countermeasures of Rural Land Circulation[J]. Special Zone Economy, 201 1(05):32-36.

[10] Li Dongwei. Analysis on Restrictive Factors and Countermeasures of Financial Support Rural Land Circulation[J]. Zhejiang Finance, 2013(02):24-28 